\title{
ОБҐРУНТУВАННЯ ОРГАНІЗАЦІЇ МЕДИКО-СОЦІОЛОГІЧНОГО МОНІТОРИНГУ ОЖИРІННЯ У ДІТЕЙ В БАГАТОПРОФІЛЬНОМУ ЗАКЛАДІ ОХОРОНИ ЗДОРОВ'Я
}

\author{
ДНУ «Науково-практичний центр профрілактичної та клінічної медицини» ДУС, м. Київ, Україна
}

\begin{abstract}
Мета: вивчити відповідність нормативно-правових, кадрових та матеріально-технічних можливостей щодо організації медико-соціологічного моніторингу ожиріння у дітей на рівні закладу охорони здоров'я та розробити програму його впровадження.

Матеріали і методи. Нормативно-правове забезпечення організації профрілактичних медичних оглядів дітей, форми обліку їх результатів, клінічний аудит з оцінки якості проведення профрілактичних медичних оглядів школярів та дані про стан їх здоров'я. Обсяг вибірки - 2081 електронних фрорм № 112/о. У роботі використано такі методи дослідження: бібліосемантичний, інсоормаційно-аналітичний, клінічного тематичного аудита, соціологічний, медикостатистичний, системного аналізу та концептуального моделювання.

Результати. Встановлено невідповідність між галузевими регламентуючими і обліковими документами у частині визначення та обліку показника «індекс маси тіла». Обґрунтовано організацію медико-соціологічного моніторингу ожиріння у дітей для закладу охорони здоров'я відповідно до Європейської ініціативи ВООз з епіднагляду за дитячим ожирінням.

Висновки. Існуюча система організації медичного спостереження за дітьми з ожирінням є недосконалою. Запровадження медико-соціологічного моніторингу ожиріння у дітей сприятиме зниженню захворюваності на ожиріння та асоційовані з ним хвороби.
\end{abstract}

КЛЮчОВІ СЛОВА: діти; надлишкова маса тіла; ожиріння; моніторинг.

Надлишкова маса тіла є однією 3 найбільш серйозних проблем громадського здоров'я, що зумовлено наслідками зростаючої поширеності ожиріння серед населення різних вікових груп у всіх країнах світу, зокрема збільшенням витрат на надання медичної допомоги, зниженням працездатності, скороченням тривалості і погіршенням якості життя людей, у зв'язку з чим ожиріння розглядають як захворювання, що має медикосоціальне значення [2, 4, 5, 9]. У країнах Європи надлишкову масу тіла мають 11-14 \%, а ожиріння 3-5 \% підлітків [6, 8]. У США поширеність ожиріння у 2011-2012 рр. серед підлітків 12-19 років становила 16,9\% [7].

Ожиріння в дитячому віці $€$ вагомим предиктором ожиріння у дорослих та фрактором ризику розвитку хвороб системи кровобігу, цукрового діабету 2 типу, захворювань суглобів, безпліддя, жирового гепатозу, гіперурикемії, злоякісних новоутворень, захворювань, що супроводжуються гіпоксією (апное уві сні). Попередження ожиріння у дитячому віці визнано одним 3 основних напрямків первинної профрілактики неінфекційних захворювань [10-12].

Відповідно до Європейської ініціативи ВОО3 з епіднагляду за дитячим ожирінням, організація безперервного, систематизованого процесу виявлення та обліку дітей з надлишковою масою тіла

(с Д.Д. Дячук, I.E. Заболотна, 2017 та ожирінням, аналіз середовища, де перебуває дитина, з позиції соціальних характеристик та поведінкових особливостей є важливим напрямком профрілактики неінфекційних захворювань [3].

Запровадження медико-соціологічного моніторингу за ожирінням на рівні закладу охорони здоров'я дозволить планувати індивідуалізовані програми профілактичних медичних оглядів, короткострокових та поглиблених профрілактичних консультувань 3 врахуванням поширеності ожиріння серед прикріпленого для медичного обслуговування дитячого населення та ризиків розвитку захворювань асоційованих із надлишковою масою тіла.

Мета дослідження: вивчити відповідність нормативно-правових, кадрових та матеріальнотехнічних можливостей щодо організації медикосоціологічного моніторингу ожиріння у дітей на рівні закладу охорони здоров'я та розробити програму його впровадження.

Матеріали і методи. Проведено аналіз галузевої нормативно-правової бази щодо організації профрілактичних медичних оглядів дітей, існуючих фрорм обліку їх результатів та клінічний аудит 3 оцінки якості проведення профрілактичних медичних оглядів дітей у дитячому консультативнолікувальному центрі ДНУ «Науково-практичний центр профрілактичної та клінічної медицини» ДУС. Проаналізовано відповідність проведення 
профрілактичних медичних оглядів дітей відповідно до вимог наказу МОЗ України від 28.07.2014 р. № 527 «Про затвердження фрорм первинної облікової документації та інструкцій щодо їх заповнення, що використовуються у закладах охорони здоров'я, які надають амбулаторно-поліклінічну допомогу населенню, незалежно від ...» у частині визначення антропометричних показників зріст, маса та відповідність оцінки фрізичного розвитку дітей щодо визначення недостатньої, нормальної та надмірної (надлишкова маса тіла та ожиріння) маси тіла за показником «індекс маси тіла» (IMT) відповідно до вимог наказу МОЗ України від 27.04.2006 р. № 254 «Про затвердження протоколів надання медичної допомоги дітям за спеціальністю «Дитяча ендокринологія» в редакції наказу МО3 України від 03.02.2009 р. № 55 «Про затвердження протоколів лікування дітей з ендокринними захворюваннями». Обсяг вибірки становив 2081 електронних форм медичної документації дітей вікової групи 7-17 років (форма № 112/о «Історія розвитку дитини № _») у частині «Профрілактичні огляди та результати оглядів дитини».

За даними медичної документації проведено аналіз стану здоров'я дітей та визначено ризики розвитку захворювань асоційованих із надлишковою масою тіла.

У роботі використано такі методи дослідження: бібліосемантичний, інорормаційно-аналітичний, клінічного тематичного аудита, соціологічний, медикостатистичний, системного аналізу та концептуального моделювання.

Результати дослідження та їх обговорення. Проведений аналіз нормативних документів показав, що кратність, механізм та обсяг фрахівців, які здійснюють профілактичні медичні огляди дітей, визначено наказом МОЗ України від 29.11.2002 р. № 434 «Про удосконалення амбулаторно-поліклінічної допомоги дітям в Україні». Порядок проведення та основні складові обов'язкових медичних профрілактичних оглядів дітей віком до 3 років визначено Клінічним протоколом медичного огляду за здоровою дитиною до 3 років, затвердженим наказом МО3 України від 20.03.2008 р. № 149, а схема періодичності обов'язкових медичних профрілактичних оглядів школярів - наказом МОЗ України від 16.08.2010 р. № 682 «Про удосконалення медичного обслуговування учнів загальноосвітніх навчальних закладів» (зареєстровано в Міністерстві юстиції України 10.09.2010 р. № 794/18089) зі змінами внесеними наказом МОЗ України від 23.05.2012 р. № 382.

Стосовно оцінки фрізичного розвитку дитини наказом МО3 України від 13.09.2013 р. № 802 «Про затвердження Критеріїв оцінки фрізичного розвитку дітей шкільного віку» (зареєстровано в Міністерстві юстиції України 02.10.2013 р. № 1694/24226) визначено, що критерієм оцінки фрізичного розвитку дітей є результати оцінки антропометричних параметрів за статево-віковими шкалами регресії, які враховують три основні показники фрізичного розвитку: зріст, масу тіла та окружність грудної клітки, а також співвідношення між цими показниками у процесі росту і розвитку дитини.

Згідно з п. 6 вимог до медичного обслуговування, оцінки стану здоров'я дітей, наказу МО3 України від 24.03.2016 р. № 234 «Про затвердження Санітарного регламенту для дошкільних навчальних закладів» (зареєстровано у Міністерстві юстиції України 14.04.2016 р. № 563/28693) обов'язкові профрілактичні медичні огляди дітей повинні відповідати наказу МОЗ України від 20.03.2008 р. № 149, та іншим нормативно-правовим актам у сорері охорони здоров'я. Для дітей віком після 3 років фрізичний розвиток (зріст, індекс маси тіла) оцінюється відповідно до вікових нормативів росту дітей різного віку і вікових індексів маси тіла у дітей, затверджених наказом МО3 України від 03.02.2009 р. № 55 «Про затвердження протоколів лікування дітей з ендокринними захворюваннями».

Облік результатів медичного огляду дитини 3 оцінкою її фрізичного розвитку проводять у фрормі № 112/o «Історія розвитку дитини № _», затвердженою наказом МО3 України від 28.07.2014 р. № 527 (інструкція заповнення зареєстрована в Міністерстві юстиції України 13.08.2014 р. № 976/25753), яка є основним медичним документом дитячих поліклінік, центрів первинної медикосанітарної допомоги, будинків дитини, закладів охорони здоров'я, що надають амбулаторно-поліклінічну допомогу, у складі яких є дитячі відділення (кабінети). Крім того, дані щодо медичних оглядів та оцінки фрізичного розвитку дитини, висновок про стан здоров'я зазначають у фрормі № 026/о «Медична карта дитини», затвердженій наказом МО3 України від 29.05.2013 р. № 435 (інструкція заповнення зареєстрована в Міністерстві юстиції України 17.06.2013 р. № 997/23529), яка заповнюється на кожну дитину, що перебуває у навчально-виховному закладі, і характеризує стан здоров'я та лікувально-профрілактичні заходи, які проводили у період перебування дитини у дошкільному навчальному закладі, загальноосвітньому навчальному закладі.

Проведення клінічного аудита у дитячому консультативно-лікувальному центрі ДНУ «Науково-практичний центр профрілактичної та клінічної медицини» ДУС у рамках оцінки якості проведення профрілактичних оглядів у частині виявлення дітей 3 надлишковою масою тіла та діагностики ожиріння шляхом ретроспективного аналізу форми № 112/о показав, що оцінка фрізичного розвитку дитини щодо визначення недостатньої, нормальної та надмірної (надлишкова маса тіла та ожиріння) маси тіла проводиться 
дільничними лікарями-педіатрами поодиноко. Оцінка фрізичного розвитку дитини за показником «індекс маси тіла» відповідно до вимог чинних медико-технологічних документів проводиться переважно дитячим лікарем-ендокринологом серед тих дітей, які направляються до нього на консультацію.

Проведення розрахунку показника «індекс маси тіла» серед дітей шкільного віку та його оцінка за перцентильними коридорами для даного віку і статі дозволило виявити ожиріння (IMT>97-го процентилю) у 75 дітей, серед яких на диспансерному обліку з приводу ожиріння (ожиріння внаслідок надлишку калорій, E66.0 та ожиріння не уточненого, Е66.9) у дитячого лікаря-ендокринолога перебувало лише 32 (42,7 \%) дитини. Решта 43 (57,3 \%) дітей у зв'язку з невизначенням IMT не були скеровані на консультацію до дитячого лікаря-ендокринолога. Крім того, виявлено 186 дітей 3 надлишковою масою тіла (IMT у межах 85-97-го процентилів).

Таким чином, результати проведеного клінічного аудита свідчать про недостатній рівень якості проведення профілактичних оглядів дільничними лікарями-педіатрами у частині оцінки ними гармонійності фрізичного розвитку школярів. Однією з основних об'єктивних причин такої ситуації $€$ відсутність єдиного стандартного підходу щодо оцінки фрізичного розвитку дитини та його гармонійності під час профрілактичних медичних оглядів внаслідок невідповідностей у регламентуючих та облікових документах. Так, фрорма № 112/о розділи XIII-XVI «Профрілактичні огляди та результати оглядів дитини ...» та фрорма № 026/о розділ VIII «Дані поглибленого медичного огляду» не передбачають визначення та облік показника «індекс маси тіла» у школярів, що утруднює отримання повноцінного уявлення щодо порушень стану здоров'я дітей.
Вивчення стану здоров'я школярів із надлишковою масою тіла та ожирінням, за даними медичної документації, показало, що надлишкова маса тіла $€$ фрактором ризику розвитку захворювань у дітей (табл.).

Із збільшенням IMT ризики розвитку захворюваності зростають, зокрема, у дітей з надлишковою масою тіла ризик розвитку розладів вегетативної нервової системи у 2 рази вищий порівняно 3 дітьми 3 нормальною масою тіла, а у дітей з ожирінням - майже у 9 разів. Ризик розвитку дискінезії жовчовивідних шляхів у школярів із надлишковою масою тіла у 2,5 раза вищий, ніж у їх однолітків, які мають нормальну масу тіла, а у дітей з ожирінням - майже у 5 разів. Також із збільшенням маси тіла підвищується ризик захворюваності на сколіоз та міопію (у дітей 3 надлишковою масою тіла у 1,8 раза та у 2,5 раза відповідно, а у дітей 3 ожирінням - у 2 рази та у 5 разів відповідно). Ризик набутої плоскостопості зі збільшенням маси тіла вище за нормальний рівень зростає у 2 рази.

Недосконалість існуючої системи просрілактики аліментарно-залежних захворювань та інформаційно-комунікативного ії супроводу, відсутність стандартизованих програм раннього виявлення надлишкової маси тіла у дітей та пов'язаних із нею порушень у стані здоров'я, організації обліку таких дітей та медичного спостереження за ними $€$ причиною недостатнього рівня діагностики ожиріння у дітей та раннього виявлення дітей з надлишковою масою тіла. Результати проведеного нами анкетного опитування лікарів загальної практики - сімейних лікарів міста Києва та Київської області показали, що індекс маси тіла визначають кожній дитині під час проведення профрілактичного огляду тільки $(29,3 \pm 4,7) \%$ лікарів. Більшість лікарів визначає індекс маси тіла лише у тому випадку, якщо у дитини візуально є надлишкова маса тіла $(66,3 \pm 4,9) \%$, разом 3 тим, $(3,3 \pm 1,9) \%$

Таблиця. Ризики розвитку захворювань при надлишковій масі тіла та ожирінні у дітей шкільного віку

\begin{tabular}{|c|c|c|c|c|}
\hline \multirow[t]{2}{*}{ Захворювання } & \multicolumn{2}{|c|}{$\begin{array}{c}\text { Надлишкова маса тіла } \\
186 \text { дітей, } 3 \text { них } 105 \text { (56,5 \%) хлопчиків } \\
\text { та } 81(43,5 \%) \text { дівчаток }\end{array}$} & \multicolumn{2}{|c|}{$\begin{array}{c}\text { Ожиріння } \\
75 \text { дітей, } 3 \text { них } 50(66,7 \text { \%) хлопчиків } \\
\text { та } 25(33,3 \%) \text { дівчаток }\end{array}$} \\
\hline & ВР, 95 \% ДІ & ВШ, 95 \% ДІ & BP, 95 \% ДІ & ВШ, 95 \% ДІ \\
\hline $\begin{array}{l}\text { Розлади вегетативної } \\
\text { нервової системи }\end{array}$ & $\begin{array}{c}2,0 \\
(0,9-4,5)\end{array}$ & $\begin{array}{c}2,1 \\
(0,9-4,8)\end{array}$ & $\begin{array}{c}7,1 \\
(3,5-14,5)\end{array}$ & $\begin{array}{c}8,9 \\
(4,0-20,0)\end{array}$ \\
\hline $\begin{array}{l}\text { Дискінезія жовчовивідних } \\
\text { шляхів }\end{array}$ & $\begin{array}{c}2,3 \\
(1,3-4,1) \\
\end{array}$ & $\begin{array}{c}2,5 \\
(1,4-4,5) \\
\end{array}$ & $\begin{array}{c}3,9 \\
(2,2-7,1)\end{array}$ & $\begin{array}{c}4,8 \\
(2,4-9,6)\end{array}$ \\
\hline Плоскостопість набута & $\begin{array}{c}2,3 \\
(1,3-4,0)\end{array}$ & $\begin{array}{c}2,5 \\
(1,4-5,0)\end{array}$ & $\begin{array}{c}1,9 \\
(0,9-4,1)\end{array}$ & $\begin{array}{c}2,1 \\
(0,9-5,0)\end{array}$ \\
\hline Сколіоз & $\begin{array}{c}1,6 \\
(1,2-2,3)\end{array}$ & $\begin{array}{c}1,8 \\
(1,2-2,8)\end{array}$ & $\begin{array}{c}1,8 \\
(1,2-2,8)\end{array}$ & $\begin{array}{c}2,1 \\
(1,2-3,8)\end{array}$ \\
\hline Міопія & $\begin{array}{c}2,3 \\
(1,3-4,1)\end{array}$ & $\begin{array}{c}2,5 \\
(1,4-4,7)\end{array}$ & $\begin{array}{c}4,1 \\
(2,3-7,4)\end{array}$ & $\begin{array}{c}5,1 \\
(2,6-10,3)\end{array}$ \\
\hline
\end{tabular}

Примітка. Ризики розраховано при порівнянні з частотою захворювань у дітей з IMT у межах 50-85-го процентилів (345 дітей, з них 185 (53,6 \%) хлопчиків та 160 (46,7 \%) дівчаток) 
респондентів зазначили, що взагалі ніколи не визначають індекс маси тіла. Серед лікарів первинної ланки надання медичної допомоги відсутня мотивація щодо спостереження за станом здоров'я дітей 3 надлишковою масою тіла, більшість 3 них вважає, що такими пацієнтами мають займатися лікарі-ендокринологи $(68,5 \pm 4,8) \%$, дієтологи $(16,3 \pm 3,9) \%$, гастроентерологи $(10,9 \pm 3,2) \%$ та лікарі-педіатри $(9,8 \pm 3,1) \%$ [1].

На основі отриманих результатів ми розробили алгоритм організації медико-соціологічного моніторингу для закладу охорони здоров'я, який передбачає виявлення дітей з надлишковою масою тіла та моніторинг за станом їх здоров'я, проведення профрілактичних втручань із застосуванням оздоровчих технологій та корекції харчової поведінки дітей (рис.). Запровадження цього підходу відповідає сучасним стратегіям та Європейській ініціативі ВОО3 з епіднагляду за дитячим ожирінням [3].

На підготовчому етапі організації медико-соціологічного моніторингу необхідне проведення клінічного аудита на рівні відповідного структурного підрозділу закладу охорони здоров'я - ретроспективної оцінки якості проведення профрілактичних медичних оглядів із метою визначення заходів, які необхідні для підвищення якості на індивідуальному, колективному або організаційному рівнях.

Результати проведеного клінічного аудита свідчать про необхідність: 1) стандартизації проведення профрілактичних медичних оглядів дітей дільничним лікарем-педіатром 3 обов'язковим включенням до протоколу первинного огляду дитини та профрілактичних оглядів із частотою 1 раз на рік (форма № 112/o «Історія розвитку дитини № _») показника «індекс маси тіла» та висновку: нормальна маса тіла, надлишкова маса тіла, ожиріння, десіцит маси тіла; 2) підвищення обізнаності дільничних лікарів-педіатрів та медичного персоналу з базовою медичною освітою з питань проведення оцінки фрізичного розвитку дітей відповідно до існуючих медико-технологічних документів та забезпечення робочих місць центильними таблицями «ндекс маси тіла у дітей».

Метою запровадження медико-соціологічного моніторингу ожиріння у дітей на рівні закладу охорони здоров'я $€$ забезпечення безперервного, систематизованого процесу виявлення та обліку дітей 3 надлишковою масою тіла та ожирінням, аналіз середовища, де перебуває дитина, з позиції соціальних характеристик та поведінкових особливостей, що дозволить планувати індивідуалізовані програми профрілактичних медичних оглядів, короткострокових і поглиблених профрілактичних консультувань та оцінювати їх ефективність.

У результаті запровадження на рівні первинної ланки надання медичної допомоги населеню програми «Медико-соціологічний моніторинг ожиріння у дітей» будуть сформовані групи підвищеного ризику розвитку ожиріння та асоційованих із ним інших найпоширеніших неінфекційних захворювань з урахуванням медичних, у т. ч. спадкових факторів та поведінкових предикторів.

Компонентами програми «Медико-соціологічний моніторинг ожиріння у дітей» виступають:

- програма скринінгу надлишкової маси тіла медична фрорма обліку;

- вивчення харчових звичок та рівня фрізичної активності - сімейна фрорма обліку (заповнюють за даними анкетування батьків);

- розробка маршруту пацієнта для подальшого медичного профрілактичного спостереження (планування щорічного профрілактичного огляду), а у разі необхідності - консультування відповідним лікарем-спеціалістом;

- профрілактичне консультування.

Програма скринінгу надлишкової маси тіла включає проведення антропометрії (визначення зросту і маси тіла, IMT), вивчення сімейного анамнезу та анамнезу життя. Інтерпретацію показників антропометрії проводять на основі таблиць фрізичного розвитку складених за методом центильних стандартів із врахуванням віку і статі. При оцінці даних сімейного анамнезу звертають увагу на наявність у родичів 1 і 2 ступенів споріднення цукрового діабету 2 типу, серцево-судинних захворювань (інфарктів, інсультів, артеріальної гіпертензії); надлишкової маси тіла або ожиріння, раку кишечника, а при оцінці анамнезу життя - на індекс маси тіла дитини у 2 роки та у 5 років. За умов наявності у дитини вищенаведених ознак сімейного анамнезу та/або перевищення індексу маси тіла у 2 роки та/або у 5 років вище ніж 85-процентиль для даного віку і статі дитину відносять до групи ризику розвитку ожиріння та асоційованих із ним неінфекційних захворювань.

Вивчення харчових звичок та рівня фрізичної активності дитини проводять методом анкетування, опитування батьків під час огляду дитини, а за умов наявності медичної інфрормаційної системи з технологією «Відкрита клініка» - заповнення анкет-опитувальників у он-лайн режимі. При оцінці харчового статусу звертають увагу на споживання на тиждень (щоденно; 2-3 рази на тиждень; 1 раз і менше) упродовж останнього місяця висококалорійних продуктів харчування (чіпси, фраст-фуд, солодощі, солодкі напої), овочів, фрруктів, м'ясних продуктів та риби. При оцінці рухової активності дитини звертають увагу на фрізичну активність високої інтенсивності (заняття спортом), хвилини/ добу, тривалість прогулянок на свіжому повітрі (тривалість години/день), час проведений за переглядом телевізора, комп'ютером (години/добу) за останній місяць.

\section{Висновки}

Недостатня діагностика ожиріння у дітей пов'язана $з$ відсутністю уніфрікованих та стандартизованих 


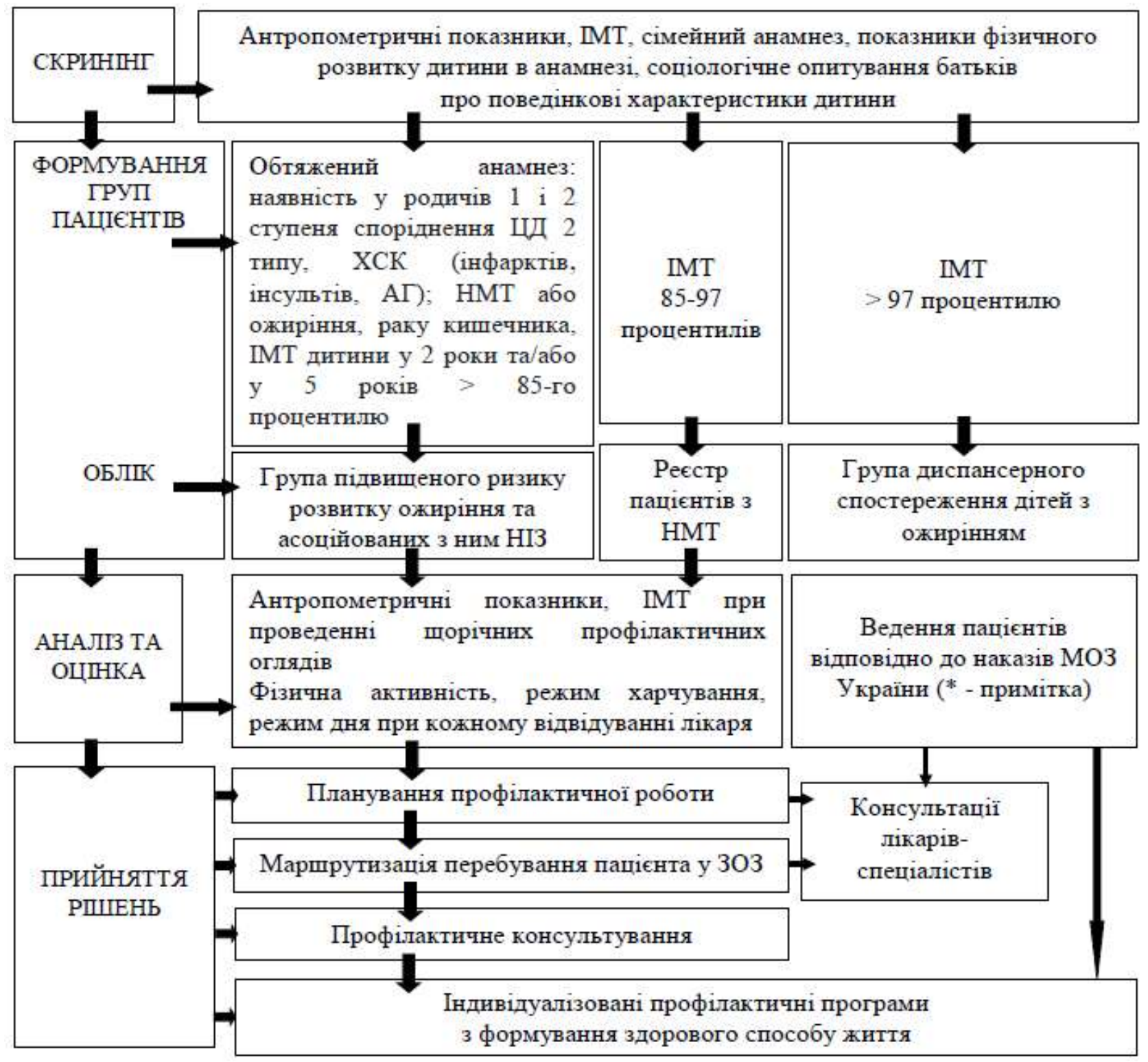

Скорочення: АГ - артеріальна гіпертензія, 303 - заклад охорони здоров'я, ІМТ - індекс маси тіла, НІ3 - неінфекційні захворювання, НМТ - надлишкова маса тіла, ХСК - хвороби системи кровообігу, ЦД - цукровий діабет.

Примітка. * - накази МОЗ України від 27.04.2006 р. № 254 в редакції наказу МОЗ України від 03.02.2009 р. № 55 «Протокол надання медичної допомоги дітям хворим на ожиріння» та від 28.05.2009 р. № 364 «Про затвердження клінічних протоколів санаторно-курортного лікування дітей в санаторно-курортних закладах України», «Клінічний протокол санаторно-курортного лікування дітей хворих на ожиріння».

\section{Рuс. Схема проведення медико-соціологічного моніторингу ожиріння у дітей.}

програм діагностики ожиріння та виявлення надлишкової маси тіла у дітей, недосконалістю існуючої системи профрілактики аліментарно-залежних захворювань, організації медичного спостереження за такими дітьми. Запровадження медико-соціологічного моніторингу фракторів ризику розвитку ожиріння, зокрема виявлення дітей групи ризику розвитку ожиріння за даними сімейного анамнезу, облік дітей з надлишковою масою тіла та ожирінням, моніторинг стану їхнього здоров'я, вивчення поведінкових фракторів ризику розвитку надлишкової маси тіла та ожиріння та їх корекція, підвищення обізнаності лікарів з проблеми ожиріння та їх мотивації до профрілактичної роботи, що відповідає сучасній стратегії ВООЗ з ліквідації ожиріння у дітей, сприятиме зниженню захворюваності серед дітей та дорослого населення на ожиріння та асоційовані з ним захворювання.

Перспективи подальших досліджень полягають у впровадженні та вивченні еорективності медико-соціологічного моніторингу ожиріння у дітей. 


\section{Список літератури}

1. Дячук Д. Д. Обізнаність сімейних лікарів з питань надлишкової маси тіла та ожиріння у дітей (за даними анкетування лікарів загальної практики - сімейних лікарів) / Д. Д. Дячук, Л. Ф. Матюха, І. Е. Заболотна // Сімейна медицина. - 2017. - № 3 (71). - С. 69-72.

2. Романцова Т. И. Эпидемия ожирения: очевидные и вероятные причины / Т. И. Романцова // Ожирение и метаболизм. - 2011. - № 1. - С. 5-19.

3. Childhood Obesity Surveillance Initiative (COSI), Protocol October 2016. WHO Regional Office for Europe, Geneva, World Health Organization, 2017. - 23 р. [Електронний ресурс]. - Режим доступу : http://www.euro.who.int/_data/ assets/pdf_file/0018/333900/COSI-protocol-en.pdf. - Назва з екрану.

4. Dang Nguyen M. The epidemiology of obesity / M. Nguyen Dang, B. El-Serag Hashem // Gastroenterol. Clin. North Am. 2010. - Vol. 39 (1). - P. 1-7.

5. Gahagan S. Overweight and obesity. In: R. M. Kliegman, B. F. Stanton, J. W. St. Geme, N. F. Schor, eds. Nelson Textbook of Pediatrics. 20th ed. - Philadelphia, PA: Elsevier, 2016.

6. Ten-year obesity and overweight prevalence in Greek children: a systematic review and meta-analysis of 2001-2010 data / E. P. Kotanidou, M. G. Grammatikopoulou, B. E. Spiliotis [et al.] // Hormones (Athens). - 2013. - Vol. 12 (4). P. 537-549.

7. Obesity - United States, 1999-2010 / A. L. May, D. Freedman, B. Sherry [et al.] // Centers for Disease Control and Prevention (CDC). MMWR. - 2013. - Vol. 62 (3). P. 120-128.

8. Miqueleiz E. Trends in the prevalence of childhood overweight and obesity according to socioeconomic status: Spain, 1987-2007 / E. Miqueleiz, L. Lostao, P. Ortega [et al.] // Eur. J. Clin. Nutr. - 2014. - Vol. 68 (2). - P. $209-214$.

9. Pêgo-Fernandes P. M. Obesity: the greatest epidemic of the 21st century? / P. M. Pêgo-Fernandes, B. J. Bibas, M. Deboni // Sao Paulo Med. J. - 2011. - Vol. 129 (5). - P. 283-284.

10. Potter C. M. Predicting adult obesity from measures in earlier life / C. M.Potter, S. J. Ulijaszek // J. Epidemiol. Community Health. - 2013. - No. 67 (12). - P. 1032-1037.

11. Prioritizing areas for action in the field of population-based prevention of childhood obesity: a set of tools for Member States to determine and identify priority areas for action: WHO Library Cataloguing-in-Publication Data, - 2010. - 90 p.

12. WHO Library Cataloguing in Publication Data. The challenge of obesity in the WHO European Region and the strategies for response / edited by F. Branca, H. Nikogosian, T. Lobstein. - Copenhagen, Denmark [Electronic resource]. - Mode access: www.euro.who.int/_data/assets/pdf_file/0010/74746/E90711.pdf. - Назва з екрану.

\section{References}

1. Diachuk, D.D., Matiukha, L.F., \& Zabolotna, I.E. (2017). Obiznanist simeinykh likariv z pytan nadlyshkovoi masy tila ta ozhyrinnia u ditei (za danymy anketuvannia likariv zahalnoi praktyky - simeinykh likariv) [Awareness of family doctors about overweight and obesity in children]. Simeina medytsyna - Family Medicine, 3 (71), 69-72 [in Ukrainian].

2. Romantsova, T.I. (2011). Epidemiya ozhireniya: ochevidnye i veroyatnye prichiny [Epidemic of obesity: obvious and probable causes]. Ozhyrenie i metabolism - Obesity and Metabolism, 1, 5-19 [in Russian].

3. Childhood Obesity Surveillance Initiative (COSI). Protocol October 2016 (2017). WHO Regional Office for Europe, 4. Geneva, World Health Organization, 23 p. - Retrieved from: http://www.euro.who.int/_data/assets/pdf_file/0018/333900/ COSI-protocol-en.pdf.

4. Dang M. Nguyen, \& El-Serag Hashem B. (2010). The epidemiology of obesity. Gastroenterol. Clin. North Am., 39 (1), 1-7.

5. Gahagan S. (2016). Overweight and obesity. Nelson Textbook of Pediatrics. 20th ed. Philadelphia, PA: Elsevier.

6. Kotanidou, E.P. Grammatikopoulou, M.G., \& Spiliotis, B.E. (2013). Ten-year obesity and overweight prevalence in Greek children: a systematic review and meta-analysis of 2001-2010 data. Hormones (Athens), 12 (4), 537-549.

7. May, A.L., Freedman, D., Sherry, B., \& Blanck, H.M. Obesity (2013). United States, 1999-2010. Centers for Disease Control and Prevention (CDC). MMWR, 62 (3), 120-128.

8. Miqueleiz, E., Lostao, L., \& Ortega, P. (2014). Trends in the prevalence of childhood overweight and obesity according to socioeconomic status: Spain, 1987-2007. Eur. J. Clin. Nutr., 68 (2), 209-214.

9. Pêgo-Fernandes, P.M., Bibas, B.J., \& Deboni, M. (2011). Obesity: the greatest epidemic of the 21st century? Sao Paulo Med. J., 129 (5), 283-284.

10. Potter, C.M., \& Ulijaszek, S.J. (2013). Predicting adult obesity from measures in earlier life. J. Epidemiol. Community Health, 67 (12), 1032-1037.

11. Prioritizing areas for action in the field of population-based prevention of childhood obesity: a set of tools for Member States to determine and identify priority areas for action (2010). WHO Library Cataloguing-in-Publication Data, 90.

12. Branca, F., Nikogosian, H., Lobstein, T. WHO Library Cataloguing in Publication Data. The challenge of obesity in the WHO European Region and the strategies for response. Copenhagen, Denmark. Retrieved from: www.euro.who.int/_data/ assets/pdf_file/0010/74746/E90711.pdf.

\section{ОБОСНОВАНИЕ ОРГАНИЗАЦИИ МЕДИКО-СОЦИОЛОГИЧЕСКОГО МОНИТОРИНГА ОЖИРЕНИЯ У ДЕТЕЙ В МНОГОПРОФИЛЬНОМ УЧРЕЖДЕНИИ ЗДРАВООХРАНЕНИЯ}

Д.Д. Дячук, И.Э. Заболотная

ГНУ «Научно-практический центр профилактической и клинической медицины» ГУД, г. Киев, Украина

Цель: изучить соответствие нормативно-правовых, кадровых и материально-технических возможностей организации медико-социологического мониторинга ожирения у детей в учреждении здравоохранения и разработать программу его внедрения. 
Материалы и методы. Нормативно-правовое обеспечение организации профилактических медицинских осмотров детей, фрормы учета их результатов, клинический аудит по оценке качества проведения профилактических медицинских осмотров школьников и данные о состоянии их здоровья. Объем выборки 2081 электронных фрорм № 112/о. В работе использованы такие методы исследования: библиосемантический, инорормационно-аналитический, клинического тематического аудита, социологический, медикостатистический, системного анализа и концептуального моделирования.

Результаты. Установлено несоответствие между отраслевыми регламентирующими и учетными документами в аспекте определения и учета показателя «индекс массы тела». Обоснована организация медико-социологического мониторинга ожирения у детей для учреждения здравоохранения в соответствии с Европейской инициативой ВОЗ по эпиднадзору за детским ожирением.

Выводы. Существующая система организации медицинского наблюдения за детьми с ожирением является несовершенной. Медико-социологический мониторинг ожирения у детей будет способствовать снижению распространенности ожирения и ассоциированных с ним заболеваний.

КЛЮЧЕВЫЕ СЛОВА: дети; избыточная масса тела; ожирение; мониторинг.

\section{RATIONALE OF THE ORGANIZATION OF MEDICAL AND SOCIOLOGICAL MONITORING OF OBESITY IN CHILDREN IN A MULTIDISCIPLINARY HEALTHCARE INSTITUTION}

\section{D.D. Dyachuck, I.E. Zabolotna}

State Scientific Institution «Scientific and Practical Center of Preventive and Clinical Medicine» State Administrative Department, Kyiv, Ukraine

Purpose: to study the compliance of regulatory, personnel and logistical possibilities regarding the organization of medical and sociological monitoring of obesity in children at the level of the health care institution and to develop a program for its implementation.

Materials and Methods. Regulatory provision of organization of preventive medical examinations of children, forms of accounting of their results, clinical audit for assessing the quality of conducting preventive medical examinations of schoolchildren and data on their health. Sample scope - 2,081 electronic forms No. 112/o.

Methods of research: bibliosemantic, informational-analytical, clinical thematic audit, sociological, medicalstatistical, system analysis and conceptual modeling.

Results. There is a discrepancy between sectoral regulatory and accounting documents in terms of determining and taking into account the index of body mass index. The organization of medical and sociological monitoring of obesity in children for the health facility is substantiated, in line with the European WHO Child Surveillance Surveillance Initiative.

Conclusion. The existing system for the organization of medical surveillance for children with obesity is imperfect. Introduction of socio-medical monitoring of obesity in children will contribute to reducing the incidence of obesity and associated diseases.

KEY WORDS: children; overweight; obesity; monitoring.

Рукопис надійшов до редакції 31.10.2017 p.

\section{Відомості про авторів:}

Дячук Дмитро Дмитрович - директор ДНУ «Науково-практичний центр профрілактичної та клінічної медицини» ДУС, член-кореспондент НАМН України, доктор медичних наук; тел.: +38(044) 284-71-06.

Заболотна Ірина Едуардівна - аспірант наукового відділу організації медичної допомоги ДНУ «Науково-практичний центр просрілактичної та клінічної медицини» ДУС; тел.: +38(044) 284-71-06. 